\title{
An Examination of Case Studies in Management Research: A Paradigmatic Bridge
}

\author{
Mehedi Masud $^{1}$ \\ ${ }^{1}$ Bangladesh Public Administration Training Centre (BPATC), Savar, Dhaka, Bangladesh, 1343 \\ Correspondence: Mehedi Masud, Bangladesh Public Administration Training Centre (BPATC), Savar, Dhaka, \\ Bangladesh, 1343.
}

Received: December 20, 2017

Accepted: January 17, $2018 \quad$ Available online: February 2, 2018

doi:10.11114/ijsss.v6i3.2971

URL: https://doi.org/10.11114/ijsss.v6i3.2971

\begin{abstract}
The paper maps the value of case study in management research. In particular, it deals with the paradigmatic aspects of case study as a research strategy. In order to analyse the convergence and divergence on different dimensions of the case study research, I focus on three well-known methodology experts, namely Robert Yin, Sharan Merriam and Robert Stake. I argue that case study is a comprehensive research strategy. It has the capacity to embrace paradigm plurality representing both inductive and deductive strategies. Because of its epistemological, ontological and methodological flexibility case study has become one of the established research approaches in management. There is no fixed set of methods for the case study research. This depends on the ontological presuppositions of the researchers. The significance of the ontology becomes apparent depending on the nature of the case and the types of the research questions. As case study research is reflexive, flexible and context-specific, it allows emerging contexts to shape methods. That is why it can act as a bridge across the research paradigms. I then look at the considerable influence that the case study approach has on the management research, i.e., the role for case study in the research process. Because of its overarching role, multi-paradigmatic approach can be adopted under case study research. Case study research is, in practice a varied methodology with paradigmatic pluralism covering an array of research methods and techniques and different levels of analysis.
\end{abstract}

Keywords: case study, research method, management, quantitative, qualitative, paradigm

\section{Introduction}

What does case study research represent in Management research? Is it quantitatively oriented along a linear deductive path underpinned by reductionism or is it a qualitative research strategy? Does it involve theory testing instead of theory building or both? Are there any fixed recipes for case study in terms of paradigm? These questions are highly relevant to case researchers.

A case study describes a management situation (Bonoma, 1985). Case study method, despite its frequent use in management research is stereotyped a less sought-after research method (Yin, 2003, 2009). The 'bad press' enjoyed by case study is partly due to the hierarchic view and partly due to the differing views of authors. This view stems from the thinking that case study research is ideal for the exploratory phase of the research and is unable to test hypothesis. Flyvbjerg (2006) observed that this stereotype may be incorrect because of traditional wisdom. In fact, case study goes well beyond exploratory phase of the investigation. Case study denotes both induction and deduction based on interpretivism and positivism respectively. According to Yin (2009), there may be exploratory case studies, explanatory case studies and descriptive case studies giving scope for both qualitative and quantitative research. Case study helps explain both the process and outcome of a phenomenon through observation and analysis of the cases under investigation as it includes both quantitative and qualitative data (Tellis, 1997, quoted in Zainal, 2007:1).

\section{Case Study in Management Research}

"The traditional school of management thought ... traced all the way back to the seventeenth century and the view of Descartes and Newton that the whole is the sum of its parts" (Gummesson, 1991, quoted in Patton et al., 2003: 61).The traditional management approach places a strong emphasis on control techniques and is based on linear thinking. A linear cause-effect relationship is based on atomised research. Accordingly, reductionism tends to distort the reality as it leads reality to compartmentalisation and structured immobility which then, no longer remains a genuine reality. The wholeness, 
thus, becomes fragmented. Fixing some engine may be best approached in this way, but fine-tuning a harmonium would not be. Patton et al. (2003: 61) noted that in this natural science approach to management, actions and behaviours are compartmentalised, and "management is viewed as a series of steps to follow; quantification and logic are the dominating forces".

However, it is increasingly evident that the natural science approach to management cannot at all times cope with the methodological issues and challenges of management science. Bertalanffy (1973) states that the laws of physics are inadequate to address social phenomena such as the study of business. According to Bertalanffy, physics is concerned with closed systems, i.e., systems that are isolated from their environment. Living organisms like businesses organisations are open systems that are always in a flux and in constant contact with their environment. Bertalanffy concludes that the method of science is "appropriate for phenomena that can be resolved into isolated causal chains, or are statistical outcome of an "infinite" number of chance processes" (quoted in Patton et al., 2003: 63).

Any management research, eventually, deals with social issues. "Ultimately, managers themselves ....in their attempt to improve operations, services or the effectiveness of organisations, deal with social systems" (Jackson, 2003, quoted in Paucar-Caceres, 2010: 47). Social issues are dynamic and complex. Moreover, social issues are context-based that require a broader comprehensive research strategy than the reductionist-compartmentalised approach. Therefore, Patton et al., (2003: 63) rightly observed that "case studies offer the opportunity for a holistic view of a process as opposed to a reductionist-fragmented view ...". According to this view, "the whole is not identical with the sum of its parts; consequently, the whole can only be understood by treating it as the central object of study" (Gummesson, 1991, quoted in Patton et al., 2003: 63). Thus, case study has long been a contested methodological terrain in management research which represents dissimilar, sometimes opposing approaches.

During the past decade, management practitioners have become increasingly interested in the case study-based research. According to Scapens (1990), researches based on case study, particularly in the UK, has benefited from the work of social theorists, such as Foucault, Habermas and Giddens. Important examples of case study research include Selznick's (1949) study of TVA, Pettigrew's (1973) study on decision-making at a British retailer, Burgelman's (1983) a process model of internal corporate venturing in the major diversified firm, Mintzberg and McHugh's (1985) strategy formation in an adhocracy, Pettigrew's (1990) longitudinal field research on change: theory and practice and Hallowell et al.'s (2002) "Four seasons goes to Paris", among others.

\section{Philosophical Assumptions Underpinning the Method: The Freedom of Paradigm}

Because of lack of consensus, differences crop up over the philosophical assumptions of the case study. Therefore, it is fundamental to explore the points of differences. As I searched the literature for the possible variances, I found that case study as a research strategy has been explored in depth mainly by three writers, Merriam (1998, 2009), Yin (1981, 1984, 1994, 1999, 2003a, 2003b, 2005, 2009, 2014), and Stake (1994, 1995, 2000, 2005, 2008). I select Yin, Merriam and Stake as they are the three seminal authors who provide procedures to follow when conducting case study research (Creswell et al., 2007). They are the principal foundational methodologists in case study research as their contributions largely impact case study design (Yazan, 2015). Ambiguities in the concept of case study surfaced with respect to philosophical assumptions as these authors interpreted the case study research in light of different perspectives. According to Verschuren (2003), divergence occurs in the case of: a) the empirical object of the case study and the way we look at it b) the research methods and c) the adequacy of the results to be obtained that are used.

I begin with Merriam first. Merriam (1998) made significant contribution to the case study research as an approach to qualitative research. Merriam (2009: 46) classified case study research into three types: 'particularistic, descriptive and heuristic'. Merriam (1998) commented that case studies have been labelled holistic, lifelike, grounded and exploratory. In other words, she viewed that case study research is grounded in data and merging that has no pre-conceived propositions. She also emphasized that case study facilitates the discovery of new meaning of the situation. In case study research, the process of inquiry is more imporant than the outcome of the research. Merriam (1998: 27) concluded that the "single most defining characteristic of case study research lies in delimiting the object of study: the case". Thus, she sees the case as a bounded system that has parts, boundaries and defined demarcations so that the entity can be "fenced in" (Merriam, 1998: 27).

Comparing case study with experimental, survey or historical research, Merriam (1998: 28) maintained that case study has no particular data collection methods. She further went on to say that "any and all methods of gathering data, from testing to interviewing, can be used in a case study...". By this, she denotes that case study is a comprehensive research strategy that can act as a bridge across the paradigms. However, she is in favour of qualitative paradigm when it comes to case study: "[The] decision to focus on qualitative case studies stems ....that this design is chosen precisely because researchers are interested in insight, discovery, and interpretation rather than hypothesis testing" (Merriam, 1998: 28-29). Merriam (1998) also supports Cronbach's (1975: 123) view that case study has been differentiated from other research 
designs by "interpretation in context" (quoted in Eldridge Jr., 1990: 146). Merriam identifies the final property of the case study as being inductive. Researchers using case study research rely upon inductive reasoning. In case study research, investigators do not enter the context with preconceived hypothesis, rather concepts and generalisations are developed from the data grounded in the particular context.

Stake (2000: 435) suggests that case studies are "one of the most common ways to do qualitative inquiry". Stake (1995) uses three terms to explain case studies: intrinsic, instrumental, and collective. The case is a particular, complex and functioning thing (Stake, 1995). The case has purposes and it often has self. It is an integrated system, and the case is more of an object of study rather than the method (Stake, 1995). Later on Stake (2000: 436) modifies his stance when he says that as an approach case study research implies, "both a process of inquiry about the case as well as the product of that inquiry." The report is also no less important to him. As Stake (2000: 435) further explains, a "case study is not a methodological choice, but a choice of what is to be studied; by whatever methods we choose to study the case." Thus, a case study is not to be pictured in terms of mere methods, which may be quantitative, qualitative, or both, but rather in terms of theoretical orientation toward a particular unit(s) of analysis (Hartley, 2004; Stake, 2000). As a matter of fact, case study is a separate research strategy. It cannot be defined through a single research method as it fosters integration of different research methods.

According to Stake (2008:119-120), case study focuses on "functioning specific" or "bounded system". Conceptualising the object is the important aspect of the qualitative case study. Stake $(2005,2008)$ believed that a case study researcher's key role is to act as an interpreter. Stake (2008: 450) is of the view that, "[The] researcher digs into meanings, working to relate them to contexts and experience. In each instance, the work is reflective". Stake (1995) based his approach to case study on constructivist paradigm. Stake (1995, quoted in Grünbaum, 2007: 84) clearly states his paradigmatic position, which is based on constructivism, "where fulfilment of external validity is not in itself considered a research goal". Although he is of the view that both qualitative and quantitative research can be undertaken through case study, Stake $(1994,1995,2000,2005,2008)$ is clearly inclined towards an interpretivist paradigm especially constructivism based on inductive reasoning.

Finally, it is evident that Stake and Merriam's stance towards case study is rooted in a paradigmatic posture that is based on a relativistic ontology that underlines the importance that knowledge transformation and creation are the outcome of the subjective and unique relationship that is constructed during the inquiry process between the inquirer and the inquired. (Grünbaum, 2007).

Turning to Yin $(2003,2009,2014)$, I discover that he is quite a methodologist. Yin $(2003,2009,2014)$ believes that case study research is not a soft research option and it should be done rigorously. Campbell who wrote the foreword of Yin's (2009) book, commented on Yin's version of case study: “..case study method be done in conformity with science's goals and methods...." (Yin, 2009: X). Yin (2009) also commented that his book is to guide researchers who intend to do case study rigorously.

There is a misconception that case studies are suitable for the exploratory phase of an inquiry (ibid, 2009). Besides being a great option for the exploratory research, case study method explains causal relationships between real life variables (Yin, 2009:15). Referring to case study Yin (2014: 199) commented, when "the process has been given careful attention, the potential result is the production of a high-quality case study".

There are two paradigms of the experimental methods that researchers can follow: randomized-assignment-to-treatments and the other one is experimental isolation paradigm. The case study approach presented by Yin (2009) is more similar to the experimental isolation paradigm in that each rival hypothesis must be controlled for and specified (Yin, 2009: viii). Here, Yin's assertion is that case study research be done in conformity with science's methods and goals (ibid). Therefore, in line with the US General Accounting Office (1990) that advanced four tests namely, trustworthiness, credibility, conformability, and data dependability, Yin also endorsed four tactics to respond to four tests relevant to case studies: construct validity, internal validity, external validity and reliability. Because, case studies are one form of empirical social research.

In response to the question: what is a case study? Yin (2014) replies, case study is an empirical inquiry about a present phenomenon, set within its real-world context - particularly when the boundaries between phenomenon and context are blurred (Yin, 2014).

Yin $(2009,2014)$ also commented that generally, case studies explore the phenomenon and generate holistic and contextual knowledge about real life events. This definition resonates with qualitative approaches that share an underpinning belief of contextual holism meaning that case study is a bridging paradigm. Hence, regarding ontological, epistemological and methodological positions, I argue that Yin's case study approach fosters integration of paradigmatic bridge. 
Moreover, case study deals with complex and dynamic social phenomena. This leads researchers to construct meaningful and holistic characteristics of real-life events (Yin, 2009: 4). This statement also denotes qualitative approach. Because qualitative methods explore dynamic social phenomena that require people-oriented approach in terms of real life experiences where the researcher seeks to understand research problems by probing, constructing and reviewing meanings and structures (Hirschman, 1986; Orlikowski and Baroudi, 1991).

At page 26, Yin (2009) commented that case study is a research method that has its own research designs. “..case study's purpose...develop or test theory" (Yin, 2009: 35) that denotes both induction and deduction based on interpretivism and positivism respectively.

That Yin's case study is a mix of both qualitative and quantitative methodology is evident by following:

"Yin's case study ... primarily does not aim at describing and understanding the phenomena... ...., the main objective....explanation of social phenomena - ... : .. investigation of cause-effect-relationships. From an epistemological.., ..., Yin's case study... is a concept .... as a methodological basis for explorative and/or explanative research. ..., rigor methods concerning data collection and analysis are indispensable for this approach …..." (Riedl, 2007: 1519).

In fact, equal treatment is highlighted. Case studies can be either qualitative or quantitative or both depending on the research questions, design and purpose (Yin 2009). He also commented, empirical research makes progresses only when it is supported by evidences and logical thinking, and not when it is approached as a mechanistic endeavour.

Yin $(2009: 17,19)$ cautions researchers not to refer case studies to qualitative research. The author disentangled case study as a research tool from ethnographies and qualitative methods. Because the essence of case study goes beyond that. Ethnographic research does not always produce case studies. Therefore, case study should not be mistaken for other strictly qualitative research paradigms.

Baxter and Jack (2008) commented that Yin based his approach to case study on a constructivist paradigm. Constructivists believe that truth is relative and follows a multi-perspective approach. This paradigm "recognizes the importance of the subjective human creation of meaning, but doesn't reject outright some notion of objectivity. Pluralism, not relativism, is stressed with... circular dynamic tension of subject and object" (Crabtree and Miller, 1999: 10). So, ontologically and epistemologically case study can be both relative and objective.

I argue, therefore, that both qualitative and quantitative approaches can be accommodated in a case study research. It all depends on the theoretical construction of the case. The particular theoretical underpinning can then be logically advanced by the researcher based in the light of the epistemological, ontological and methodological approach. Because of its paradigmatic flexibility, case study has become a useful research strategy within both the positivist and the interpretivist philosophy (Cavaye, 1996; Doolin, 1996; Darke, Shanks, and Broadbent, 1998).

Several authors concur that qualitative methods should be used in the case study (Ragin, 1989; Creswell 1998; Stake 1995, 1998; Gillham, 2000). In qualitative tradition, case study is described as a significant qualitative strategy along with phenomenology, ethnography, biography, and grounded theory (Crotty, 1998, Creswell, 2003, Denzin \& Lincoln, 2005, 2008, Guba \& Lincoln, 1994, Mertens, 2005, Hatch, 2002, Patton, 1990; quoted in Brown, 2008). Some others postulate that in a case study, a variety of labour-intensive methods are to be employed (Campbell, 1975, Creswell, 1994; quoted in Verschuren, 2003). Evidently, case study represents a significant research strategy not only as a method for quantitative tradition, but also for qualitative tradition.

Case study method emphasises theory building in research but also incorporates prior theory, and so is a blend of induction and deduction (Perry, 1998). Yin (2009: 19) also endorsed Perry's view that case studies be based on any mix of deduction and induction depending on research questions.

Therefore, case study approaches can act as a paradigmatic bridge as a separate research strategy. "Case studies are... used across the objectivist problematic and the subjectivist problematic but written in very different ways as factual accounts ... organisational members' experiences" (Cunliffe, 2010: 13). Cavaye (1996) also maintained that it can be used in various ways from within different research perspectives using a variety of data collection and analysis methods, and producing diverse types of research outcomes. Topical publications endorse that as case study accommodates evidences from a variety of sources and cover multiple realities (Jones \& Lyons, 2004), it has the potential to bridge paradigms (Luck, Jackson, \& Usher, 2006).

Case study research can employ various data collection processes i.e., participant observation, document analysis, surveys, questionnaires, interviews, delphi processes, and others. "This unique characteristic - the ability of the researcher to use the observations of a single unit or subject, or contextual case, as the focal point of a study, along with its plurality as a research method - has enabled case study research to transcend the boundaries of traditional research paradigms" (Dooley, 2002: 338). These characteristics and properties of the case study approach places it in a 
multi-paradigm research strategy. Noticing such unique characteristics, Lynham (2002) maintains that within multiparadigm theory-building research, case study research can be used as a strategy for integrating and complementing multiple research methods.

Case study places emphasis on multiple sources of evidence and covers multiple realities (Jones \& Lyons, 2004). And, the potential to bridge paradigms (Luck et al., 2006) is in fact, the strength of the case study (Brown, 2008).

I suggest that qualitative approach is best suited for case study. Because, I believe that case study approach aims to increase ecological validity as it places emphasis on real-life context. For example, if an intervention leads to an improvement in a respondent's wellbeing, then this is a far more valid theoretical proposition than any statistically supported theoretical proposition (Jones et al., 2004).

Using a naturalistic approach, qualitative research seeks to understand phenomena in context-specific settings, such as "real world setting [where] the researcher does not attempt to manipulate the phenomenon of interest" (Patton, 2002: 39). Patton (2002) intends to assert that in order to qualify for a qualitative research it has to be naturalistic, contextual and must be in a real world setting so that manipulation is not possible. This statement perfectly reflects the definition of qualitative case study by Yin (2003). According to Yin $(2003,2009)$, case study is an inquiry that investigates a contemporary case (phenomenon) in depth and within its real-life context when the boundary between the observed case and context is not clearly observable. He also observed that in case studies, relevant behaviour cannot be manipulated. Yin's $(2003,2009)$ above-mentioned definition also advances that case study should be contextual and conducted in real-life setting where behaviours cannot be manipulated. While the purpose of overall design of the qualitative inquiry is to answer research questions which the case study does, the main aim of qualitative research is to achieve an in-depth and holistic understanding of what is being studied (Scapens, 2006). In fact, case study is an inductively done in-depth investigation into the real world context of the case being explored. Qualitative research is ideal for capturing holistic picture. In qualitative approach, a researcher gets a holistic picture, where idiosyncrasies are important for meaning. In so doing, the researcher uses an inductive mode, letting the data speak (Ospina, 2004). Similarly Yin affirmed (2009: 4), “..case study... allows investigators to retain...holistic...meaningful characteristics of real-life events - such as individuals life cycles, organizational....processes, ...”.

Case study is ideal for understanding complex social phenomena. Case study research offers the opportunity for a holistic view of a phenomenon (Yin, 2003, 2009). This statement by Yin perfectly justifies qualitative approach. Because qualitative methods usually explores complex social phenomena that are based on real life experiences.

\section{Research Methods to Be Used}

For the purpose of the argument, I maintain that methods are procedures, activities, tools and techniques used to acquire evidence like interviewing in a questionnaire, observing behaviour etc. (Crotty, 1998; Minger, 1997). There is no agreed set of methods for the case study research. This depends on the ontological presuppositions of the researchers. The significance of the ontology becomes apparent depending on the nature of the case and the types of the research question. Ideally, case study is appropriate when a research question starts with how or why and is asked about a contemporary case over which researchers have little or no control (Yin, 2003, 2009). Thus, case study can be considered a comprehensive approach or research strategy (Dale, 1995; Yin, 2003, 2009) as it can encompass a variety of methods.

Case study research offers the opportunity for using a variety of evidences from different sources. Multiple sources of evidences allow the researchers to address multiple reality based on data triangulation. For data collection, case study researchers follow certain procedures that include tasks such as the skills training of investigators, the preparation of case study protocols, the conduct of pilot case studies, and the actual implementation of a case study research plan (Yin, 2003, 2009). While collecting data, case study methodologists should take account of three principles. First, use of multiple sources of evidence that allows four types of triangulation - data triangulation, investigator triangulation, theory triangulation, methodological triangulation. Second, creating a case study data base and third, maintaining a chain of evidence (Yin, 2003, 2009; Patton, 1987).

Yin (2009) maintained that while the chain of evidence increases the reliability of the information of the case study, the case study database may consist of tabular materials including survey and quantitative data. A good number of case studies have been conducted and are being conducted using quantitative research method and both. One good example of such a case study is a book by Gross et al. (1971) titled Implementing Organizational Innovations: A Sociological Analysis of Planned Educational Change where both the observational and survey data led to quantitative information about attitudes in the school whereas the open-ended interviews led to the qualitative information. In fact, the case study findings were based on the convergence of information from both the quantitative and qualitative information.

Following Dooley (2002: 338), I hold that "the power of case study research is the ability to use all methodologies 
within the data-collection process and to compare within case and across case for research validity". Here, Case study research follows a rigorous protocol for data collection namely, the case study protocol which is a central communication document for the data collection team.

Case studies do not provide single slice of data. Rather, case studies provide a rounded and detailed description called thick description (Greetz, 1973). Compared to the single slice of data provided by a survey, case studies look through multiple lenses, historiography, document analysis and participant-observation among others.

\section{Influences on Research Process}

An example from the Chinese metaphysics states that the tree seen in a garden is the same tree all year long; its essence - fundamental reality - remains the same, though it takes multiple appearances throughout the year. A tree can be experienced with or without flowers, with green leaves, then with brown leaves and ultimately a tree with no leaves. The tree has different appearances and why can't the appearances be real? "The tree can be perceived eventfully, relationally, with respect to all the seasons, other natural phenomena, and with respect to ourselves as well (Ames and Rosemont, 1998: 21). The bottom line is, like the tree, the world is eventful - events are changing based on contexts. And, case study is best when employed for contextual knowledge (Yin, 2009) and changing phenomena.

I hold that case study method has a considerable impact on the research process representing problem discovery, research questions, data collection and analysis, theoretical sampling, triangulation, pattern-matching logic, objectivity, validity and analytical generalisation. Because of importance of case study in research process, it has become a common research strategy in psychology, sociology, business, political science and community planning (Gilgun, 1994; Ghauri and Grønhaug, 2002; quoted in Yin, 2003:1). Case study enables a deeper level of understanding of the respondents which is not possible in survey method. This is because of the smaller distance between the researcher and the researched (Kasanen, Lukka, \& Siitonen, 1993; Parker, 2007).

There are three criteria that determine the best research methodology:

- The types of research questions

- The extent of control over behavioural events

- The degree of focus on contemporary phenomena as opposed to historical events (Yin, 2009).

Case study research fulfils all that factors and hence Yin (2009) defines it as a comprehensive research strategy. Forms/patterns of research questions give important clues regarding the appropriate research design. Therefore, framing appropriate research questions is the significant step in the research (Yin, 2009) which the case study research responds to perfectly. It has perfectly categorised the types of research questions appropriate for the case study research. For example, how and why type of questions lead to the case study research.

A suitable role for case study method is dealing with contemporary events in which relevant behaviour of the people cannot be manipulated because of the natural setting (Yin, 2009). According to Yin (2009), in contrast, in experiments an investigator manipulates behaviour directly, precisely and systematically in a laboratory setting. This case study method role is also supported by two other sources of evidences that are of limited use to other methods - direct observation and systematic interviewing, which can usefully supplement other sources of evidence like documents, archival materials, surveys etc. Typically, case study research collects data from different sources including interviews, documents, artefacts, and observation, some of which are not possible in historical study.

Case study methods that use multiple sources of evidence are important in research process in terms of contemporary and changing events where researchers have less control. Because by applying multiple sources researchers, can collect impartial data based on data triangulation. In experimental or quasi-experimental study, the data collection and analysis methods are known to hide some details (Stake, 1995). Case studies, on the other hand, have potentials to bring out the details from the viewpoint of the participants by extracting data from multiple sources (Tellis, 1997).

Positivists criticise case study for being prone to bias, less-rigorous and less-generalisabile (Jasen and Rodgers 2001). However, bias can access other research strategies i.e., designing questionnaires for surveys (Sudman and Bradburn, 1982). The four design tests of construct validity, internal validity, external validity and reliability are commonly applied to the theoretical paradigm of positivism (Riege, 2003). Case study approach also enjoys integrity or rigour of validity through five approaches: construct validity; confirmability; internal validity/credibility; external validity/transferability and finally, reliability/dependability (Miles and Huberman, 1994). Yin (2009, 2014) also recommended four tests as good case study tactics: construct validity, internal validity, external validity and reliability.

For increasing the construct validity, multiple sources of evidence in data collection phase are used. The most important advantage presented by the multiple sources of evidence is the development of the converging lines of inquiry (Yin, 2003, 2009; Flick, 1992; Perakyla, 1997). The use of multiple sources of evidence contribute to the methodological 
rigour in case study (Creswell, 1998; Yin, 2009). Any case study findings will be credible if it is based on different sources of information, following a 'corroborative' model (Yin, 2003, 2009).

In a quantitative research, internal validity refers to the degree to which a research establishes a cause-and-effect relationship. In a case study, the emphasis is on constructing an internally valid research process in establishing phenomena in a credible manner (Riege, 2003). The internal validity is ensured in case studies by three techniques pattern matching, explanation building, addressing rival explanations and using logic models (Yin, 2009, 2014).

Case study's external validity relies on analytic generalisations whereby a theory is generalised to some broader theory.

Establishment of chain of evidence increases the reliability in case study. The principle is to follow the route of evidence from the first research question to conclusions (Yin, 2009).

It is important to note that good theoretical and literal replication is possible from the case studies. Multiple-case design follows a replication (Yin, 2009). For establishing rigour and objectivity case studies can accommodate collection and analysis of highly quantitative data. According to Yin (2003: 53), "when an ...each ..case study may in fact include the collection and analysis of highly quantitative data, including the use of surveys within each case." It is true that theoretical replication vastly increases the external validity of the research leading to the reliability, validity, objectivity and replicablity of the study. Therefore, case study method has greater impact in the research process.

Yin (2009) developed tactics to overcome subjectivity of the case study research process. He proposed to use a case study protocol to deal with documentation problem. The development of a case study database can positively affect the reliability of case study. Yin (2009) said that the protocol is a significant way of increasing objectivity of case study. Techniques like pattern matching, time series, logic model, and cross-case synthesis are used by case study to increase objectivity.

One more important procedure to follow is to have the draft report reviewed not just by the peers but also by the participants. Yin (2009: 183) commented that in doing so methodologically, if there are any corrections it will certainly enhance the construct validity of the study.

Case study definition by Yin $(2003,2009)$ reflects that the strength of case studies is its ability to investigate inductively a phenomenon in its real life context. The natural setting itself is like a natural laboratory as contrasted with controlled environment of a laboratory. Unlike statistical generalisation, here analytic generalisation occurs through replication.

However, generalisations on the findings cannot be extended to the population (Yin, 2003, 2009). Again the need for generalisation derives from a positivist approach in which generalisation on the basis of samples is the norm. But this view of Yin underpins the qualitative methodology. Because he is not in favour of statistical inferences made about a population/universe. According to Yin (2009: 38), "A fatal flaw ...case studies is to conceive of statistical generalizations as the method of generalizing the results of your case study. ...because... cases are not 'sampling units'... ." He also argues, under these circumstances, the mode of generalisation is analytic generalisations when conducting a case study. This analytic generalisation is called level two inferences. Yin (2009, 39) commented, “.... should aim for level two inferences when doing case studies."

Accordingly, portraying real life situations inductively based on contextual generalisation is the strength of the case study. The interest of case study is in contextual generalisation rather than a specific variable.

The role of researchers in view of above is to exercise great care in designating case study to overcome the traditional criticisms of the method (Yin, 2003, 2009). One way of ensuring this is to have the data corroborated by the research subjects. In case studies, distance between researcher and subjects is small. Case researchers make an effort to outline the limitations of the research within the study in order to contextualise the research findings. Case researchers should be good listeners and be adaptive and flexible (Yin, 2003, 2009). Hence, case researchers exercise ethical practice.

Yin (2014) advances four different dimensions for case study: first, case study goal is to explain a situation inductively in the form of a causal relationship that is too complex for the survey or experimental strategies. While in the natural sciences universal truths are sought, case studies aim at making broader conclusions, generalisable to theoretical propositions and not to population. The second application of case studies is to describe real-life contexts in which an intervention has occurred. Third, it describes the nature and types of intervention itself. Fourth, the case study strategy may be used to explore those situations in which the action being assessed has no comprehensible, single set of outcomes. This last application indicates that case studies are useful not only as a method for inductive theory generation but for theory testing (Patton and Appelbaum, 2003).

\section{Conclusion}

Case study research is a reliable methodology when conducted with care. It is, in fact, not a soft option as Yin (2003, 2009) remarked that case study research is remarkably hard. Case study has the reflexibility to address newly generated contexts 
and problems. Flyvbjerg (2006: 242), in his defence of case study research, concludes that "good social science research is problem driven and not methodology driven." Because of its applicability, case study research has been adopted within both the positivist and interpretivist philosophical traditions (Darke et al., 1998).

Luck et al. (2006) argued that the variation and flexibility in meanings and use of case study research acknowledge the need for paradigmatic flexibility. In the same vein, I also argue that case study is a tough research methodology and it offers a flexible, pragmatic and yet a rigorous approach to research. Also, case study offers a bridge across the paradigms. I suggest that in fact, the potential to bridge paradigms is the strength of the case study as it enjoys methodological openness and pluralism. In fact, weaknesses of the case study research can be converted to strengths.

Positivist tradition criticises case study evidence for its limitations vis-à-vis empirical research (Bryar, 1999). But Dooley (2002) dismisses it by arguing that case study research transcends the boundaries of traditional research paradigms . Actually, these criticisms no longer apply to case study research as it is a separate research strategy "that is informed by philosophical tenets, theoretical perspectives and the researchers' applied definition of 'the case"' (Luck et al., 2006: 108).

\section{References}

Ames, R., \& Rosemont, H. (1998). The analects of Confucius: A philosophical translation. New York, NY: Random House

Baxter, P., \& Jack, S. (2008). Qualitative Case Study Methodology: Study Design and Implementation for Novice Researchers. The Qualitative Report, 13(4), 544-559, Retrieved from http://www.nova.edu/ssss/QR/QR13-4/baxter.pdf

Bertalanffy, L. V. (1973). La Théorie Générale Des Système. Paris: Dunod.

Bonoma, T. V. (1985). Case Research in Marketing: Opportunities, Problems, and a Process. Journal of Marketing Research, XXII, 199-208. https://doi.org/10.2307/3151365

Brown, P. A. (2008). A Review of the Literature on Case Study Research. Canadian Journal for New Scholars in Education, 1(1), 1-13, Retrieved from http://www.cjnse-rcjce.ca/ojs2/index.php/cjnse/article/download/23/20

Bryar, R. M. (1999). An Examination of Case Study Research. Nurse Researcher, 7, 61-78.

Burgelman, R. (1983). A Process Model of Internal Corporate Venturing in a Major Diversified Firm. Administrative Science Quarterly, 28(2), 223-244. https://doi.org/10.2307/2392619

Campbell, D. T. (1975). Degrees of Freedom and the Case Study. Comparative Political Studies, 8(2), 178-193. https://doi.org/10.1177/001041407500800204

Cavaye, A. L. M. (1996). Case study research: A multi-faceted research approach for IS. Information Systems Journal, 6 , 227-242. https://doi.org/10.1111/j.1365-2575.1996.tb00015.x

Crabtree, B., \& Miller, W. (1999). Doing Qualitative Research (2nd ed.). London: Sage Publications.

Creswell, J. W., Hanson, W. E., Plano, V. L. C., \& Morales, A. (2007). Qualitative Research Designs Selection and Implementation. The Counseling Psychologist, 35(2), 236-264. https://doi.org/10.1177/0011000006287390

Creswell, J. W. (1994). Research Design: Qualitative and Quantitative approaches. Thousand Oaks, CA: Sage Publications, Inc.

Creswell, J. W. (1998). Qualitative Inquiry and Research Design: Choosing Among Five Traditions. Thousand Oaks, CA: Sage Publications, Inc.

Creswell, J. W. (2003). Research Design; Qualitative, Quantitative, and Mixed Methods Approaches (2nd ed.). Thousand Oaks, CA: Sage Publications, Inc.

Cronbach, L. J. (1975). Beyond the Two Disciplines of Scientific Psychology. American Psychologist, 30(2), 116-127. https://doi.org/10.1037/h0076829

Crotty, M. (1998). The Foundations of Social Research. St Leonards, NSW: Allen \& Unwin.

Cunliffe, A. L. (2010). Crafting Qualitative Research: Morgan and Smircich 30 Years On. Organizational Research Methods, 14(4), 647-673. https://doi.org/10.1177/1094428110373658

Dale, A. (1995). A Research Study Exploring The Patient's View of Quality of Life Using The Case Study Method. Journal of Advanced Nursing, 22(6), 1128-1134. https://doi.org/10.1111/j.1365-2648.1995.tb03114.x

Darke, P., Shanks, G., \& Broadbent, M. (1998). Successfully Completing Case Study Research: Combining Rigour, Relevance and Pragmatism. Information Systems Journal, 8(1), 273-289.

https://doi.org/10.1046/j.1365-2575.1998.00040.x 
Denzin, N. K., \& Lincoln, Y. S. (2005). Introduction: The Discipline and Practice of Qualitative Research. In N. K. Denzin, and Y. S. Lincoln, The Sage Handbook of Qualitative Research (3rd ed., pp. 1-32). Thousand Oaks, CA: Sage.

Denzin, N. K., \& Lincoln, Y. S. (2008). Introduction: The Discipline and Practice of Qualitative Research, In N. K. Denzin, and Y. S. Lincoln, Strategies of Qualitative Inquiry (3rd ed., pp. 1-44). Thousand Oaks, CA: Sage.

Dooley, L. M. (2002). Case Study Research and Theory Building. Advances in Developing Human Resources, 4(3), 335-354. https://doi.org/10.1177/1523422302043007

Doolin, B. (1996). Alternative Views of Case Research in Information Systems. Australian Journal of Information Systems, 3, 21-29. https://doi.org/10.3127/ajis.v3i2.383

Eldridge, Jr. R. G. (1990). Developing Case Studies to Prepare Reading Educators, In B. L. Hayes, Ed. and K. Camperell, Achieving Excellence in Reading, Yearbook of the American Reading Forum (Ed.). Volume X, Retrieved from http://www.eric.ed.gov/contentdelivery/servlet/ERICServlet?accno=ED326856

Flick, U. (1992). Triangulation Revisited: Strategy of or Alternative to Validation of Qualitative Data. Journal for the Theory of Social Behavior, 22(2), 175-197. https://doi.org/10.1111/j.1468-5914.1992.tb00215.x

Flyvbjerg, B (2006). Five Misunderstandings About Case-study Research. Qualitative Inquiry, 12(2), 219-245. https://doi.org/10.1177/1077800405284363

Ghauri, P., \& Grønhaug, K. (2002). Research Methods in Business Studies (2nd ed.). Essex, Harlow: Pearson Education Limited.

Gilgun, J. F. (1994). Hand into Glove: The Grounded Theory Approach and Social Work Practice Research. In Sherman, E. \& Reid, W. J. (Ed.), Qualitative Research in Social Work? (pp. 115-125). New York, NY: Columbia University Press.

Gillham, B. (2000). Case Study Research Methods. London: Continuum.

Gordon, I. R., \& McCann, P. (2005). Innovation, Agglomeration, and Regional Development. Journal of Economic Geography, 5(5), 523-543. https://doi.org/10.1093/jeg/lbh072

Greetz, C. (1973). Thick Description: Toward an Interpretive Theory of Culture. In Greetz, C. (Ed.), The Interpretation of Cultures (pp. 3-30). New York, NY: Basic Books.

Gross, N., Joseph, B. G., \& Marilyn, B. (1971). Implementing Organizational Innovations: A Sociological Analysis of Planned Educational Change. New York, NY: Basic Book.

Grünbaum, N. N. (2007). Identification of Ambiguity in the Case Study Research Typology: What is a Unit of Analysis? Qualitative Market Research: An International Journal, 10(1), 78-97. https://doi.org/10.1108/13522750710720413

Guba, E. G., \& Lincoln, Y. S. (1994). Competing Paradigms in Qualitative Research. In N. K. Denzin and Y.S. Lincoln (Eds.), Handbook of Qualitative Research (pp. 105-117). Thousand Oaks, CA: Sage.

Gummesson, E. (1991). Qualitative Methods in Management Research. Newbury Park, California: Sage Publications.

Hallowell, R., Bowen, D. E., \& Knoop, C. I. (2002). Four Seasons Goes to Paris. Academy of Management Executive, 16(4), 7-24. https://doi.org/10.5465/AME.2002.8951308

Hartley, J. (2004). Case Study Research. In C. Cassell \& G. Symon (Eds.), Essential Guide to Qualitative Methods in Organizational Research (pp.323-333). London: Sage. https://doi.org/10.4135/9781446280119.n26

Hatch, J. A. (2002). Doing Qualitative Research in Education Settings, Albany: State University of New York.

Hirschman, E. C. (1986). Humanistic Inquiry in Marketing Research: Philosophy, Method, and Criteria. Journal of Marketing Research, 23(3), 237-249. https://doi.org/10.2307/3151482

Jackson, M. C. (2003). Systems Thinking: Creative Holism for Managers. Chichester, England: John Wiley and Sons Ltd.

Jasen, L. J., \& Rodgers, R. (2001). Cumulating the Intellectual Gold of Case Study Research. Public Administration Review, 61(2), 235-246. https://doi.org/10.1111/0033-3352.00025

Jones, C., \& Lyons, C. (2004). Case study: Design? Method? Or Comprehensive Strategy? Nurse Researcher, 11(3), 70-76. https://doi.org/10.7748/nr2004.04.11.3.70.c6206

Kasanen, E., Lukka, K., \& Siitonen, A. (1993). The Constructive Approach in Management Accounting Research. Journal of Management Accounting Research, 5, 243-264.

Luck, L., Jackson, D., \& Usher, K. (2006). Case Study: A Bridge Across the Paradigms. Nursing Inquiry, 13(2), 103-109. 
https://doi.org/10.1111/j.1440-1800.2006.00309.x

Lynham, S. A. (2002). The General Method of Theory-building Research in Applied Disciplines. Advances in Developing Human Resources, 4(3), 221-241. https://doi.org/10.1177/1523422302043002

Merriam, S. B. (1998). Qualitative Research and Case Study Applications in Education. San Francisco: Jossey-Bass.

Merriam, S. B. (2009). Qualitative Research: A Guide to Design and Implementation (3rd ed.). San Francisco: Jossey-Bass.

Mertens, D. M. (2005). Research and Evaluation in Education and Psychology: Integrating Diversity with Quantitative, Qualitative, and Mixed Methods (2nd ed.). Thousand Oaks, CA: Sage.

Miles, M. B., \& Huberman, A. M. (1994). Qualitative Data Analysis: An Expanded Sourcebook of New Methods. Thousand Oaks, CA: Sage.

Mingers, J. (1997). Towards Critical Pluralism. In J. Mingers, and A. Gill (ed.), Multimethodology: Towards Theory and Practice for Mixing and Matching Methodologies (pp. 407-440). Chichester: John Wiley and Sons.

Mintzberg, H., \& McHugh, A. (1985). Strategy Formation in An Adhocracy. Administrative Science Quarterly, 30(2), 160-197. https://doi.org/10.2307/2393104

Orlikowski, W. J., \& Baroudi, J. J. (1991). Studying Information Technology in Organisations: Research Approaches and Assumption. Information Systems Research, 2(1), 1-14. https://doi.org/10.1287/isre.2.1.1

Ospina, S. (2004). Qualitative Research. In G. R. Goethals, G. S. Sorenson \& J. M. Burns (Eds.), Encyclopedia of Leadership ( pp. 1279-1284). Thousand Oaks, CA: Sage Publication

Parker, L. (2007). Interpreting Interpretive Accounting Research. Critical Perspectives on Accounting, 19(6), 909-914. https://doi.org/10.1016/j.cpa.2007.03.013

Patton, E., \& Appelbaum, S. H. (2003). The Case for Case Studies in Management Research. Management Research News, 26(5), 60-71. https://doi.org/10.1108/01409170310783484

Patton, M. Q. (1990). Qualitative Evaluation and Research Methods, Newbury Park, CA: Sage.

Patton, M. Q. (2002). Qualitative Evaluation and Research Methods (3rd ed.). Thousand Oaks, CA: Sage Publications, Inc.

Patton, M. Q. (1987). How to Use Qualitative Methods in Evaluation, Newbury Park, CA: Sage.

Paucar-Caceres, A. (2010). Mapping the Changes in Management Science: A Review of Soft OR/MS Articles Published in Omega (1973-2008). Omega, 38 (1-2), 46-56. https://doi.org/10.1016/j.omega.2009.04.001

Perakyla, A. (1997). Reliability and Validity in Research Based on Tapes and Transcripts. In Silverman, D. (ed.), Qualitative Research: Theory, Method and Practice (pp.201-220). London: Sage Publications.

Perry, C. (1998). Processes of a Case Study Methodology for Postgraduate Research in Marketing. European Journal of Marketing, 32(9/10), 785-802. https://doi.org/10.1108/03090569810232237

Pettigrew, A. (1973). The Politics of Organizational Decision making, London: Tavistock.

Pettigrew, A. (1990). Longitudinal Field Research on Change: Theory and Practice. Organization Science, 1(3), $267-292$. https://doi.org/10.1287/orsc.1.3.267

Ragin, C. C. (1989). The Comparative Method: Moving Beyond Qualitative and Quantitative Strategies, Berkeley: University of California Press.

Riedl, R. (2007). On the replication of positivist case study research. In Österle, H., Schelp, J. \& Winter, R. (Ed.), Proceedings of the 15th European Conference on Information Systems (pp.1515-1526). Switzerland: St. Gallen.

Riege, M. A. (2003). Validity and Reliability Test in Case Study Research: A literature Review with "Hands-on" Applications for Each Research Phase. Qualitative Market Research: An International Journal, 6(2), 75-86. https://doi.org/10.1108/13522750310470055

Scapens, R. W. (1990). Researching Management Accounting Practice: The Role of Case Study Methods. The British Accounting Review, 22, 259-281. https://doi.org/10.1016/0890-8389(90)90008-6

Scapens, R. W. (2006). Understanding Management Accounting Practices: A Personal Journey. The British Accounting Review, 38, 1-30. https://doi.org/10.1016/j.bar.2005.10.002

Selznick, P. (1949). TVA and the Grass Roots. Berkeley, CA: University of California Press.

Stake, R. E. (1994). Case Studies. In N. K. Denzin, \& Y.S Lincoln (Eds.), Handbook of Qualitative Research (pp. 
236-247). Thousand Oaks, CA: Sage.

Stake, R. E. (2005). Qualitative Case Studies. In N. K. Denzin, \& Y.S. Lincoln (Eds.), The Sage Handbook of Qualitative Research (3rd ed., pp. 443-466). Thousand Oaks, CA: Sage.

Stake, R. E. (2008). Qualitative Case Studies, In N. K. Denzin, \&Y. S. Lincoln (Eds.), Strategies of Qualitative Inquiry, $\left(3^{\text {rd }}\right.$ ed., pp. 119-150).Thousand Oaks, CA: Sage.

Stake, R. E. (2000). Case Studies. In N. K. Denzin \& Y. S. Lincoln (Eds.), Handbook of Qualitative Research (2nd ed., pp.435-453). Thousand Oaks, CA: Sage.

Stake, R. E. (1995). The Art of Case Study Research, Thousand Oaks, CA: Sage Publications, Inc.

Sudman, S., \& Bradburn, M. N. (1982). Asking Questions: A Practical guide to Questionnaire Design, San Francisco: Jossey-Bass.

Tellis, W. (1997). Introduction to Case Study, The Qualitative Report, 3(2). Retrieved from Available, http://www.nova.edu/ssss/QR/QR3-2/tellis1.html

U.S. General Accounting Office, Program Evaluation and Methodology Division. (1990). Case Study Evaluations. Washington, D.C.: Government Printing Office.

Verschuren, P. J. M. (2003). Case Study As a Research Strategy: Some Ambiguities and Opportunities. International Journal of Social Research Methodology, 6(2), 121-139. https://doi.org/10.1080/13645570110106154

Yazan, B. (2015). Three Approaches to Case Study Methods in Education: Yin, Merriam, and Stake. The Qualitative Report, 20(2), 134-152.

Yin, R. K. (2014). Case Study Research Design and Methods (5th ed.). Thousand Oaks, CA: Sage.

Yin, R. K. (1981). The Case Study Crisis: Some Answers. Administrative Science Quarterly, 26(1), 58-65. https://doi.org/10.2307/2392599

Yin, R. K. (1994). Case Study Research: Design and Methods (2nd ed.). Thousand Oaks, CA: Sage.

Yin, R. K. (1999). Enhancing the Quality of Case Studies in Health Services Research. Health Services Research, 34(5), 1209-1224.

Yin, R. K. (2003a). Applications of Case Study Research (2nd ed.). Thousand Oaks, CA: Sage.

Yin, R. K. (2003b). Case Study Research: Design and Methods (3rd ed.). Thousand Oaks, CA: Sage.

Yin, R. K. (2005). “Introduction”. In R. K. Yin, Introducing the World of Education: A Case Study Reader (ed., pp. xiii-xxii). Thousand Oaks, CA: Sage.

Yin, R. K. (2009). Case Study Research: Design and Methods (4th ed.). Thousand Oaks, CA: Sage.

Yin, R. K. (1984). Case Study Research: Design and Methods. Beverly Hills, CA: Sage.

Zainal, Z. (2007). Case study as a research method. Jurnal Kemanusiaan, bil.9, Retrieved from http://eprints.utm.my/8221/1/ZZainal2007-Case_study_as_a_Research.pdf

\section{Copyrights}

Copyright for this article is retained by the author(s), with first publication rights granted to the journal.

This is an open-access article distributed under the terms and conditions of the Creative Commons Attribution license which permits unrestricted use, distribution, and reproduction in any medium, provided the original work is properly cited. 